\title{
Mode of delivery and gut microbiota
}

\author{
Vito Leonardo Miniello*, Angela Colasanto, Lucia Diaferio, Laura Ficele, Maria Serena Leggi, Valentina Santoiemma \\ From XX National Congress of the Italian Society of Neonatology \\ Rome, Italy. 9-11 October 2014
}

In 1985 the World Health Organization (WHO) stated: "There is no justification for any region to have Caesarean Section (CS) rates higher than 10-15\%"[1]. During the last decades the percentage of births managed by CS has increased beyond the recommended level, especially in high income areas such as Italy, Germany, France, United Kingdom, and North America [2,3].

Emerging evidences indicate that the early composition of neonatal gut microbiota is responsible for shaping of immune response since there is a complex interaction between the intestinal microbiome and the immune system (Gut-Associated Lymphoid Tissue) and this crosstalk is involved in maintaining normal immune homeostasis [4]. The microbiome promotes human health, but can also drive disease. The potential disadvantages of caesarean delivery include altered bacterial profile known as dysbiosis of the gut microbiota which in turn leads to immune dysfunction and increased tendency for immune-mediated diseases such as allergies $[5,6]$ and autoimmunity [7].

Upon delivery, the neonate is exposed to a wide variety of microbes, many of which are provided by the mother during and after the passage through the birth canal, a heavily colonized ecosystem. The neonatal colonization pattern is further influenced by several postnatal environmental factors such as the place and mode of delivery, the level of affluence, the number of siblings, the use of antibiotics and infant feeding.

The reduced microbial exposure and delayed colonization occurring in caesarean born infants have been associated with the development of allergic disease. CS delivered infants, deprived of contact with the maternal vaginal microbiota, experience a deficiency of strict anaerobes such as Bacteroides, E. coli, and bifidobacteria and a higher presence of facultative anaerobes such as Clostridium species, compared with vaginally born infants [8].

It is debated whether a low total diversity of the gut microbiota during infancy is more important than an altered prevalence of particular bacterial species (Clostridia) for the increasing incidence of allergic disease $[5,6]$. Recently Bisgaard et al. demonstrated that reduced diversity of intestinal microbiota during infancy is associated with increased risk of allergic disease during childhood [9].

The concept of probiotics has attracted increasing attention in recent years since several clinical studies have been published suggesting that probiotics may convert a dysbiosis to a symbiosis in infants with inadequate intestinal colonization (premature delivery, delivery by CS and excessive use of perinatal antibiotics) [10-15]. Clinical evidences suggest that probiotics could substantially affect metabolic and immunomodulatory functions [16].

\section{Published: 9 October 2014}

\section{References}

1. World Health Organization: Appropriate technology for birth. Lancet 1985, 2:436-7.

2. MacDorman MF, Menacker F, Declercq E: Cesarean birth in the United States: epidemiology, trends, and outcomes. Clin Perinatol 2008, 35:293-307.

3. Zizza A, Tinelli A, Malvasi A, Barbone E, Stark M, De Donno A, Guido M: Caesarean section in the world: a new ecological approach. $J$ Prev Med Hyg 2011, 52:161-73.

4. Chung H, Kasper DL: Microbiota-stimulated immune mechanisms to maintain gut homeostasis. Curr Opin Immunol 2010, 22:455-460.

5. van Nimwegen FA, Penders J, Stobberingh EE, Postma DS, Koppelman GH, et al: Mode and place of delivery, gastrointestinal microbiota, and their influence on asthma and atopy. J Allergy Clin Immunol 2011, 128:948-955.

6. Penders J, Thijs C, van den Brandt PA, Kummeling I, Snijders B, Stelma F, Adams $H$, van Ree R, Stobberingh EE: Gut microbiota composition and development of atopic manifestations in infancy: the KOALA Birth Cohort Study. Gut 2007, 56:661-667.

7. Cardwell CR, Stene LC, Joner G, Cinek O, Svensson J, Goldacre MJ: Caesarean section is associated with an increased risk of childhoodonset type 1 diabetes mellitus: a meta-analysis of observational studies. Diabetologia 2008, 51:726-735.

8. Adlerberth I, Wold AE: Establishment of the gut microbiota in Western infants. Acta Paediatrica 2009, 98:229-238.

9. Bisgaard H, Li N, Bonnelykke K, Chawes BL, Skov T, Paludan-Müller G, Stokholm J, Smith B, Krogfelt KA: Reduced diversity of the intestinal microbiota during infancy is associated with increased risk of allergic disease at school age. J Allergy Clin Immunol 2011, 128:646-652. 
10. Prescott SL, Björkstén B: Probiotics for the prevention or treatment of allergic diseases. J Allergy Clin Immunol 2007, 120:255-62.

11. Pfefferle PI, Prescott SL, Kopp M: Microbial influence on tolerance and opportunities for intervention with prebiotics/probiotics and bacterial lysates. J Allergy Clin Immunol 2013, 131:1453-63.

12. Hardy H, Harris J, Lyon E, Beal J, Foey AD: Probiotics, prebiotics and immunomodulation of gut mucosal defences: homeostasis and immunopathology. Nutrients 2013, 29:1869-1912.

13. Weng $M$, Walker WA: The role of gut microbiota in programming the immune phenotype. J Dev Orig Health Dis 2013, 4:203-214.

14. Bezirtzoglou E, Stavropoulou E: Immunology and probiotic impact of the newborn and young children intestinal microflora. Anaerobe 2011, 17:369-374.

15. Kuitunen M, Kukkonen K, Juntunen-Backman K, Korpela R, Poussa T, Tuure T, Haahtela T, Savilahti E: Probiotics prevent IgE-associated allergy until age 5 years in cesarean-delivered children but not in the total cohort. J Allergy Clin Immunol 2009, 123:335-341.

16. Walker WA: Initial intestinal colonization in the human infant and immune homeostasis. Ann Nutr Metab 2013, 63(Suppl 2):8-15.

\section{Submit your next manuscript to BioMed Central} and take full advantage of:

- Convenient online submission

- Thorough peer review

- No space constraints or color figure charges

- Immediate publication on acceptance

- Inclusion in PubMed, CAS, Scopus and Google Scholar

- Research which is freely available for redistribution

Submit your manuscript at www.biomedcentral.com/submit 